\title{
IDH1 mutant glioma is preferentially sensitive to the HDAC inhibitor panobinostat
}

\author{
Thomas K. Sears ${ }^{1,3} \cdot$ Craig M. Horbinski ${ }^{1,2} \cdot$ Kevin D. Woolard ${ }^{3}$
}

Received: 10 June 2021 / Accepted: 13 August 2021 / Published online: 23 August 2021

(c) The Author(s) 2021

\begin{abstract}
Introduction A large subset of diffusely infiltrative gliomas contains a gain-of-function mutation in isocitrate dehydrogenase 1 or 2 (IDH1/2 ${ }^{\mathrm{mut}}$ ) which produces 2-hydroxglutarate, an inhibitor of $\alpha$-ketoglutarate-dependent DNA demethylases, thereby inducing widespread DNA and histone methylation. Because histone deacetylase (HDAC) enzymes are localized to methylated chromatin via methyl-binding domain proteins, IDH1/2 ${ }^{\text {mut }}$ gliomas may be more dependent on HDAC activity, and therefore may be more sensitive to HDAC inhibitors.

Methods Six cultured patient-derived glioma cell lines, $\operatorname{IDH} 1^{\mathrm{wt}}(\mathrm{n}=3)$ and IDH1 ${ }^{\text {mut }}(\mathrm{n}=3)$, were treated with an FDAapproved HDAC inhibitor, panobinostat. Cellular cytotoxicity and proliferation assays were conducted by flow cytometry. Histone modifications and cell signaling pathways were assessed using immunoblot and/or ELISA.

Results IDH $1^{\text {mut }}$ gliomas exhibited marked upregulation of genes associated with the HDAC activity. Glioma cell cultures bearing IDH $1^{\text {mut }}$ were significantly more sensitive to the cytotoxic and antiproliferative effects of panobinostat, compared to $\mathrm{IDH}{ }^{\mathrm{wt}}$ glioma cells. Panobinostat caused a greater increase in acetylation of the histone residues H3K14, H3K18, and H3K27 in IDH $1^{\text {mut }}$ glioma cells. Another HDAC inhibitor, valproic acid, was also more effective against IDH ${ }^{\text {mut }}$ glioma cells.

Conclusion These data suggest that IDH $1^{\text {mut }}$ gliomas may be preferentially sensitive to HDAC inhibitors. Further, IDH $1^{\text {mut }}$ glioma cultures showed enhanced accumulation of acetylated histone residues in response to panobinostat treatment, suggesting a direct epigenetic mechanism for this sensitivity. This provides a rationale for further exploration of HDAC inhibitors against IDH1 ${ }^{\text {mut }}$ gliomas.
\end{abstract}

Keywords Isocitrate dehydrogenase (IDH) mutant glioma · Histone deacetylase (HDAC) inhibition · Panobinostat · Valproic acid

\section{Introduction}

Mutations in isocitrate dehydrogenase 1 and 2 (termed $\mathrm{IDH} 1 / 2^{\mathrm{mut}}$ ) are present in approximately $25-30 \%$ of all diffusely infiltrative gliomas in adults, and are now part of the diagnostic criteria for oligodendrogliomas [1]. Single point mutations at key arginine amino acid residues cause a dramatic change in enzyme activity, where $\alpha$-ketoglutarate is

Thomas K. Sears

thomas.sears@northwestern.edu

1 Department of Neurological Surgery, Northwestern University, Chicago, IL, USA

2 Department of Pathology, Northwestern University, Chicago, IL, USA

3 Department of Pathology, Immunology, and Microbiology, UC Davis School of Veterinary Medicine, Davis, CA, USA converted into D-2-hydroxyglutarate (D2HG) [2]. D2HG, in turn, inhibits certain DNA- and histone-demethylating dioxygenases that require $\alpha$-ketoglutarate as a co-substrate. This gradually leads to a global increase in DNA and histone methylation in IDH1/2 ${ }^{\text {mut }}$ gliomas [3-5]. While the exact mechanisms connecting this cellular activity to gliomagenesis are not yet completely understood, IDH $1 / 2^{\text {mut }}$ gliomas are generally much less aggressive than their IDH1/2 wild-type $\left(\mathrm{IDH}^{\mathrm{wt}}\right)$ counterparts. In fact, the distinction is so dramatic that the new World Health Organization (WHO) scheme has split adult-type infiltrative gliomas into three discrete subsets: "Astrocytoma, IDH1/2 ${ }^{\text {mut }}$, WHO grades 2-4," "Oligodendroglioma, IDH $1 / 2^{\text {mut }}$ and $1 \mathrm{p} / 19 \mathrm{q}$-codeleted, WHO grades 2-3" and "Glioblastoma, IDH1/2 ${ }^{\text {wt }}$, WHO grade 4" [6].

Since IDH $1 / 2^{\text {mut }}$ occurs early in gliomagenesis, and the histone/DNA hypermethylation state of IDH1/2 $2^{\text {mut }}$ gliomas 
is largely retained even during disease progression [7-10], there is a possibility that epigenetic modifiers may be particularly effective against IDH $1 / 2^{\text {mut }}$ glioma. Histone deacetylases (HDACs) are a class of epigenetic "erasers" that promote chromatin compaction via removal of acetate residues from acetylated histones [11]. HDACs form complexes with methyl-binding domain (MBD) [12] and/or MeCP2 proteins [13], particularly the NuRD complex, which includes HDAC $1 / 2$ and MBD2/3 [14-17]. This interaction directs HDAC enzymes to methylated DNA to facilitate chromatin compaction and epigenetic repression of genes associated with these methylated DNA regions. We therefore sought to determine whether IDH $1 / 2^{\text {mut }}$ gliomas might be preferentially sensitive to HDAC inhibitors (HDACi), which are already being used to treat malignancies elsewhere in the body [18].

\section{Results}

\section{Genes that promote HDAC function are upregulated in IDH1/2mut glioma}

First, gene expression profiles from The Cancer Genome Atlas (TCGA) and the Chinese Glioma Genome Atlas (CGGA) were analyzed $[19,20]$. IDH $1 / 2^{\mathrm{wt}}$ and IDH1/2 ${ }^{\mathrm{mut}}$ glioma samples were matched by grade (Grade $2 / 3$ versus Grade 4) and subsequently subjected to differential gene expression analysis. Differentially expressed genes (DEGs) were further evaluated via gene ontology (GO) analysis. In both Grade 4 datasets from TCGA and CGGA, IDH1/2 status was significantly associated with upregulation of genes that modulate HDAC activity (Fig. 1b, d). In the low grade glioma cohort, this effect was only observed in the TCGA dataset, though this was not statistically significant based on adjusted p-value estimates (Fig. 1a, c). Nevertheless, 8/11 of the HDAC-related genes identified via GO analysis are significantly upregulated in the low grade TCGA and CGGA datasets (Fig. S1). HDAC-related genes upregulated in IDH1/2 ${ }^{\text {mut }}$ glioma include HDAC2/4/5, KDM1A, CHD4, MTA2/3, SIRT1/2, PHF21A, and BRMS1L. These data support the concept that IDH1/2 ${ }^{\text {mut }}$ gliomas have increased activity in HDAC pathways, and suggests targeting histone acetylation via HDAC inhibitors may exhibit profound effects in IDH $1 / 2^{\text {mut }}$ glioma.

\section{Characterization of IDH expression and activity in glioma cell lines}

To assess the effect of HDAC inhibition on glioma based on IDH1/2 status, we employed six patient-derived glioma cell lines: three IDH1/2 $2^{\text {wt }}(0827,0923,0211)$ and three IDH $1^{\text {mut }}$ (0905, BT142, TB096). No patient-derived IDH2 ${ }^{\text {mut }}$ glioma cell lines were used as they are extremely rare (only $2.3 \%$ of all glioma patients bear an IDH2 ${ }^{\text {mut }}$ ) [21]. Of the three IDH $1{ }^{\text {mut }}$ glioma cell lines, two contain the canonical heterozygous R132H mutation (0905, TB096) while BT142 has a hemizygous $\mathrm{R} 132 \mathrm{H}$ mutation, with the wild-type allele having been lost. Information on clinical pathology and other relevant genetic alterations, are provided in Table S1. IDH1 R132H expression was confirmed using western blot and reflected the genomic status for each line, with BT142 exhibiting enhanced production of the mutant R132H IDH1 enzyme (Fig. S2a). D2HG quantitation via ELISA also showed that 0905 and TB096 cell lines produced higher levels of D2HG, whereas BT142 more closely resembled IDH1/2 ${ }^{\text {wt }}$ glioma cells (Fig. S2b), consistent with prior studies indicating that both IDH $1^{\mathrm{wt}}$ and IDH $1^{\text {mut }}$ alleles are required for prominent $\mathrm{D} 2 \mathrm{HG}$ production [8, 22-24].

\section{IDH1 ${ }^{\text {mut }}$ glioma cells display increased cytotoxicity with HDAC inhibition}

Viability of IDH $1 / 2^{\text {wt }}$ and IDH $1^{\text {mut }}$ glioma cells was determined using DNA chromophore cell viability and Annexin $\mathrm{V}$ apoptosis assays. In cell viability dose-response assays, IDH $1^{\text {mut }}$ glioma cells were much more sensitive to an FDAapproved pan-HDACi, panobinostat, compared to their IDH $1 / 2^{\text {wt }}$ counterparts, with a 4.1 fold difference in $\mathrm{IC}_{50}$ values (Fig. 2a, b; Fig. S3; Table S2). This response was not dependent on culture conditions, as IDH $1^{\text {mut }}$ cells cultured in serum-free glioma stem cells (0905 and BT142) and in serum-containing media (TB096) showed the same heightened sensitivity. Annexin V apoptosis dose-response assays showed an even more pronounced sensitivity to panobinostat in IDH $1^{\text {mut }}$ cells, with a tenfold difference in average $\mathrm{EC}_{50}$ values compared to IDH1/2 ${ }^{\text {wt }}$ (Fig. 2c, d; Fig. S4; Table S2). (The disparity of magnitude between the apoptosis and cell viability data is likely due to the apoptosis assay detecting cells that were still viable, but were in early phases of apoptosis.) Western blot analysis showed selective induction of cleaved caspase-3 (CC3) exclusively in IDH1 ${ }^{\text {mut }}$ glioma cells cultured with $10 \mathrm{nM}$ panobinostat (Fig. 2e), confirming that panobinostat triggers apoptosis in these cells.

Furthermore, phase-contrast microscopy images showed that 0827 and 0923 IDH $1 / 2^{\text {wt }}$ cells retained sphere size and number in culture when treated with $10 \mathrm{nM}$ panobinostat for 5 days, whereas IDH $1^{\text {mut }}$ cells exhibited visible signs of cytotoxicity, including reduction in sphere size, sphere number, and a pronounced increase in single cells that were phase-dark (Fig. 2f). To examine whether these data simply reflect a general chemosensitivity in IDH $1^{\text {mut }}$ cells, both IDH $1 / 2^{\text {wt }}$ and IDH $1^{\text {mut }}$ cells were subjected to puromycin dose-response assays, which showed no difference in sensitivity based on IDH status (Fig. S5; Table S3). Together, these data suggest that IDH1 ${ }^{\text {mut }}$ glioma cells are 
TCGA Grade 2/3

\begin{tabular}{|c|c|c|c|c|c|}
\hline Rank & Term & P-value & Adj. P-value & Odds Ratio & Combined Score \\
\hline 1 & polynucleotide adenylyltransferase activity (GO:0004652) & 0.009 & 0.295 & 19.6 & 92.8 \\
\hline 2 & satellite DNA binding (GO:0003696) & 0.012 & 0.300 & 15.7 & 69.2 \\
\hline 3 & m7G(5')pppN diphosphatase activity (GO:0050072) & 0.012 & 0.300 & 15.7 & 692 \\
\hline 4 & hydrolase activity, acting on acid anhydrides, in phosphorus-containing anhydrides (GO:0016818) & 0.020 & 0.379 & 11.2 & 43.8 \\
\hline 5 & Notch binding (GO:0005112) & 0.008 & 0.295 & 8.4 & 40.4 \\
\hline 6 & translation initiation factor activity (GO:0003743) & 0.002 & 0.240 & 6.3 & 39.7 \\
\hline 7 & G-rich strand telomeric DNA binding (GO:0098505) & 0.025 & 0.434 & 9.8 & $\square 36.3$ \\
\hline 8 & histone deacetylase activity (GO:0004407) & 0.003 & 0.240 & 5.6 & 32.5 \\
\hline 9 & nucleotide diphosphatase activity (GO:0004551) & 0.030 & 0.434 & 8.7 & 30.6 \\
\hline 10 & translation factor activity, RNA binding (GO:0008135) & 0.001 & 0.240 & 4.6 & 30.2 \\
\hline 11 & protein deacetylase activity (GO:0033558) & 0.004 & 0.240 & 5.3 & 29.6 \\
\hline 12 & microtubule plus-end binding (GO:0051010) & 0.035 & 0.434 & 7.8 & 26.3 \\
\hline 13 & pseudouridine synthase activity (GO:0009982) & 0.035 & 0.434 & 7.8 & च 26.3 \\
\hline 14 & single-stranded telomeric DNA binding (GO:0043047) & 0.035 & 0.434 & 7.8 & 26.3 \\
\hline 15 & BMP receptor binding (GO:0070700) & 0.035 & 0.434 & 7.8 & $\square 26.3$ \\
\hline
\end{tabular}

TCGA Grade 4

\begin{tabular}{|c|c|c|c|c|c|}
\hline \multicolumn{6}{|c|}{ TCGA Grade 4} \\
\hline Rank & Term & P-value & Adj. P-value & Odds Ratio & Combined Score \\
\hline 1 & histone demethylase activity (H3-K9 specific) (GO:0032454) & 0.000 & 0.020 & 11.9 & 97.4 \\
\hline 2 & ubiquitin-ubiquitin ligase activity (G0:0034450) & 0.000 & 0.020 & 11.9 & 97.4 \\
\hline 3 & helicase activity (GO:0004386) & 0.000 & 0.006 & 6.9 & 71.4 \\
\hline 4 & intronic transcription regulatory region sequence-specific DNA binding (GO:0001161) & 0.006 & 0.107 & 11.4 & 58.9 \\
\hline 5 & phosphatidylinositol-3,5-bisphosphate 3-phosphatase activity (GO:0052629) & 0.002 & 0.054 & 9.5 & 58.2 \\
\hline 6 & phosphatidylinositol monophosphate phosphatase activity (GO:0052744) & 0.004 & 0.086 & 7.6 & 41.8 \\
\hline 7 & phosphatidylinositol-3-phosphatase activity (GO:0004438) & 0.004 & 0.086 & 7.6 & 41.8 \\
\hline 8 & RNA binding (GO:0003723) & 0.000 & 0.000 & 1.9 & - 38.4 \\
\hline 9 & microtubule minus-end binding (GO:0051011) & 0.011 & 0.181 & 8.2 & $\square 36.5$ \\
\hline 10 & phosphatidylinositol-3,5-bisphosphate phosphatase activity (GO:0106018) & 0.005 & 0.105 & 6.9 & \36.1 \\
\hline 11 & histone deacetylase activity (GO:0004407) & 0.001 & 0.030 & 4.8 & $\square 34.7$ \\
\hline 12 & DNA binding (GO:0003677) & 0.000 & 0.000 & 2.0 & $\square 33.0$ \\
\hline 13 & chromo shadow domain binding (GO:0070087) & 0.033 & 0.338 & 9.5 & 32.5 \\
\hline 14 & 7SK snRNA binding (GO:0097322) & 0.033 & 0.338 & 9.5 & $\square 2.5$ \\
\hline 15 & RNA polymerase II intronic transcription regulatory sequence-specific DNA binding (GO:000 & 0.033 & 0.338 & 9.5 & 32.5 \\
\hline
\end{tabular}

\begin{tabular}{|c|c|c|c|c|c|}
\hline \multicolumn{6}{|c|}{ CGGA Grade 2/3 } \\
\hline Rank & Term & P-value & Adj. P-value & Odds Ratio & Combined Score \\
\hline 1 & neurotransmitter receptor activity regulating postsynaptic membrane potential (GO:0099529) & 0.000 & 0.004 & 15.8 & 182.7 \\
\hline 2 & glutamate receptor activity (GO:0008066) & 0.000 & 0.022 & 13.1 & 119.8 \\
\hline 3 & filamin binding (GO:0031005) & 0.002 & 0.120 & 16.8 & 107.9 \\
\hline 4 & ionotropic glutamate receptor activity (GO:0004970) & 0.001 & 0.049 & 13.1 & 98.2 \\
\hline 5 & acetyl-CoA C-acyltransferase activity (GO:0003988) & 0.009 & 0.350 & 19.6 & 92.8 \\
\hline 6 & transmitter-gated ion channel activity (GO:0022824) & 0.000 & 0.022 & 8.8 & 77.3 \\
\hline 7 & AT DNA binding (GO:0003680) & 0.012 & 0.363 & 15.7 & च 69.2 \\
\hline 8 & transmitter-gated ion channel activity regulating postsynaptic membrane potential (GO:1904315) & 0.000 & 0.027 & 7.9 & $\square 65.6$ \\
\hline 9 & 3-hydroxyacyl-CoA dehydrogenase activity (GO:0003857) & 0.016 & 0.363 & 13.0 & 54.1 \\
\hline 10 & RNA polymerase I regulatory region sequence-specific DNA binding (GO:0001163) & 0.016 & 0.363 & 13.0 & ए54.1 \\
\hline 11 & sulfurtransferase activity (GO:0016783) & 0.016 & 0.363 & 13.0 & 54.1 \\
\hline 12 & RNA polymerase I CORE element sequence-specific DNA binding (GO:0001164) & 0.016 & 0.363 & 13.0 & 54.1 \\
\hline 13 & enoyl-CoA hydratase activity (GO:0004300) & 0.016 & 0.363 & 13.0 & $\square 4.1$ \\
\hline 14 & phosphatase activator activity (GO:0019211) & 0.020 & 0.400 & 11.2 & $\square \quad 43.8$ \\
\hline 15 & neurexin family protein binding (GO:0042043) & 0.025 & 0.416 & 9.8 & 36.3 \\
\hline
\end{tabular}

\begin{tabular}{|c|c|c|c|c|c|c|}
\hline \multicolumn{7}{|c|}{ CGGA Grade 4} \\
\hline Rank & Term & P-value & Adj. P-value & Odds Ratio & Comb & bined Score \\
\hline 1 & histone demethylase activity (H3-K9 specific) (GO:0032454) & 0.000 & 0.002 & 16.4 & $\bar{\square}$ & 177.6 \\
\hline 2 & microtubule minus-end binding (GO:0051011) & 0.001 & 0.057 & 12.7 & - & 87.5 \\
\hline 3 & m7G(5')pppN diphosphatase activity (GO:0050072) & 0.004 & 0.102 & 14.3 & 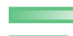 & 79.8 \\
\hline 4 & GDP-dissociation inhibitor activity (GO:0005092) & 0.006 & 0.140 & 11.4 & $\square$ & 58.9 \\
\hline 5 & nucleosomal DNA binding (GO:0031492) & 0.000 & 0.039 & 6.1 & $\square$ & 46.8 \\
\hline 6 & hydrolase activity, acting on acid anhydrides, in phosphorus-containing anhydrides (GO:0016818) & 0.008 & 0.174 & 9.5 & $\square$ & 45.6 \\
\hline 7 & tubulin binding (GO:0015631) & 0.000 & 0.000 & 2.9 & $\square$ & 41.6 \\
\hline 8 & glutamate receptor activity (GO:0008066) & 0.003 & 0.100 & 6.4 & $\square$ & 38.0 \\
\hline 9 & phosphotransferase activity, for other substituted phosphate groups (GO:0016780) & 0.011 & 0.182 & 8.2 & $\square$ & 36.5 \\
\hline 10 & microtubule binding (GO:0008017) & 0.000 & 0.001 & 3.0 & $\square$ & 36.3 \\
\hline 11 & histone deacetylase activity (GO:0004407) & 0.001 & 0.053 & 4.8 & $\square$ & 34.7 \\
\hline 12 & neurotransmitter receptor activity regulating postsynaptic membrane potential (GO:0099529) & 0.003 & 0.100 & 6.0 & $\square$ & 34.2 \\
\hline 13 & histone acetyltransferase activity (GO:0004402) & 0.001 & 0.056 & 4.6 & $\square$ & 32.9 \\
\hline 14 & JUN kinase binding (GO:0008432) & 0.033 & 0.282 & 9.5 & $\square$ & 32.5 \\
\hline 15 & RNA polymerase I core binding (GO:0001042) & 0.033 & 0.282 & 9.5 & $\square$ & 32.5 \\
\hline
\end{tabular}

Fig. 1 Genes involved in promoting HDAC activity are upregulated in IDH $1^{\text {mut }}$ glioma. a-d Gene ontology (GO) analysis of TCGA and CGGA datasets showing that genes which facilitate HDAC func- tion are upregulated in IDH1/2 ${ }^{\text {mut }}$ glioma. The top 15 GO terms are ranked based on Combined Score, and the GO term relating to HDAC activity is highlighted in yellow 
a

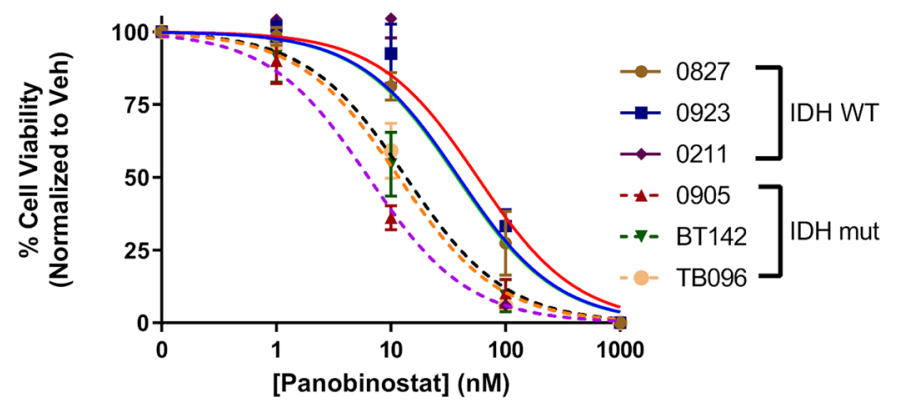

C

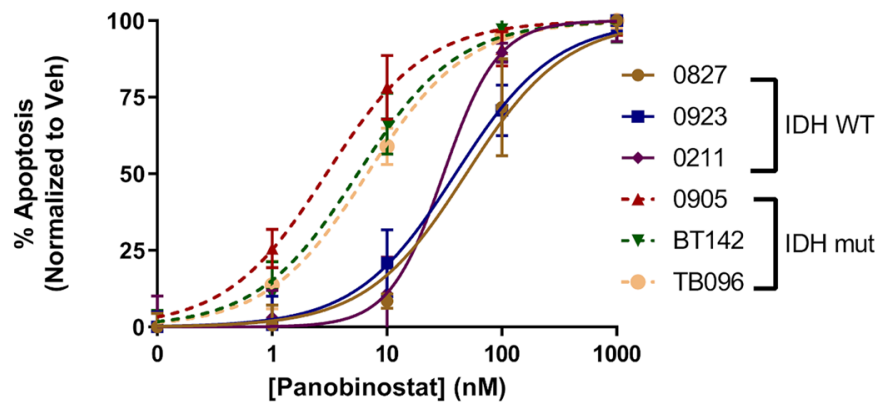

b

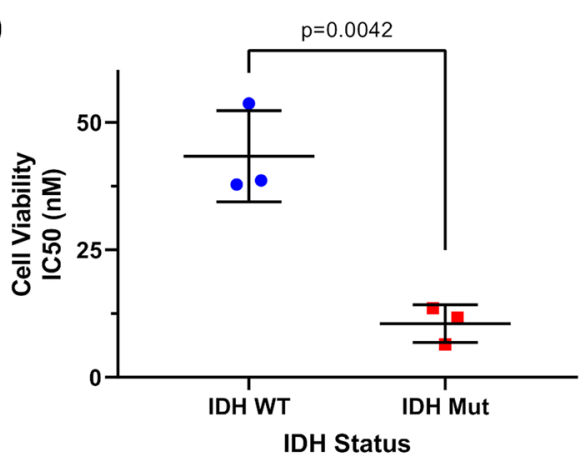

d

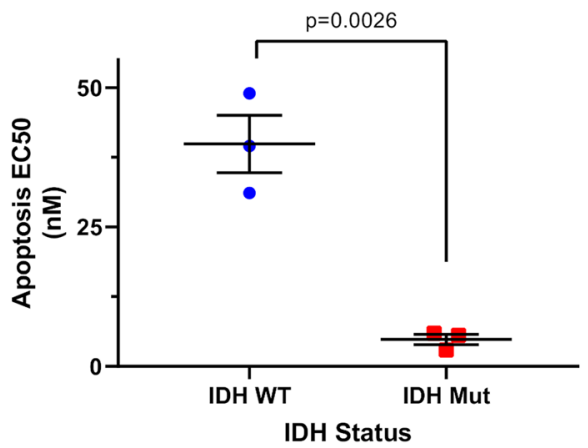

e

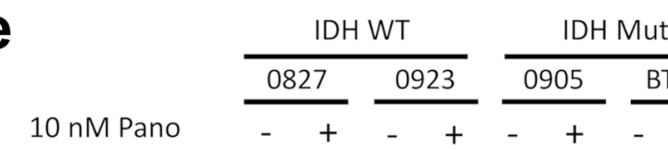

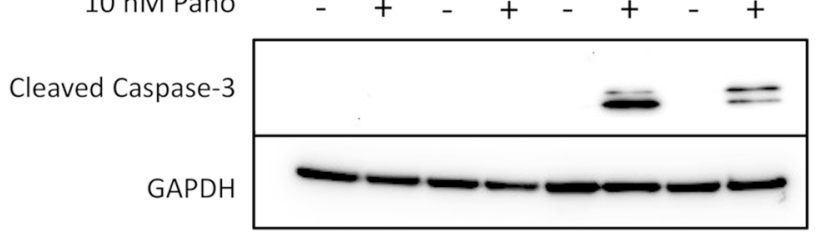

Fig. 2 IDH $1^{\text {mut }}$ glioma is particularly sensitive to the cytotoxic effects of panobinostat. a Normalized cell viability of IDH $1 / 2^{\mathrm{wt}}$ and mutant glioma cells treated with the HDAC inhibitor panobinostat for 5 days $(n=3)$. Nonlinear regression statistical analysis was utilized to determine IC50 values. b Consolidation of cell viability IC50 values derived from a stratified based on IDH status $(n=9)$. Statistical analysis was performed via Student's t-test. $\mathbf{c}$ Induction of apoptosis in IDH $1 / 2^{\text {wt }}$ and IDH $1^{\text {mut }}$ glioma cells treated with panobinostat for

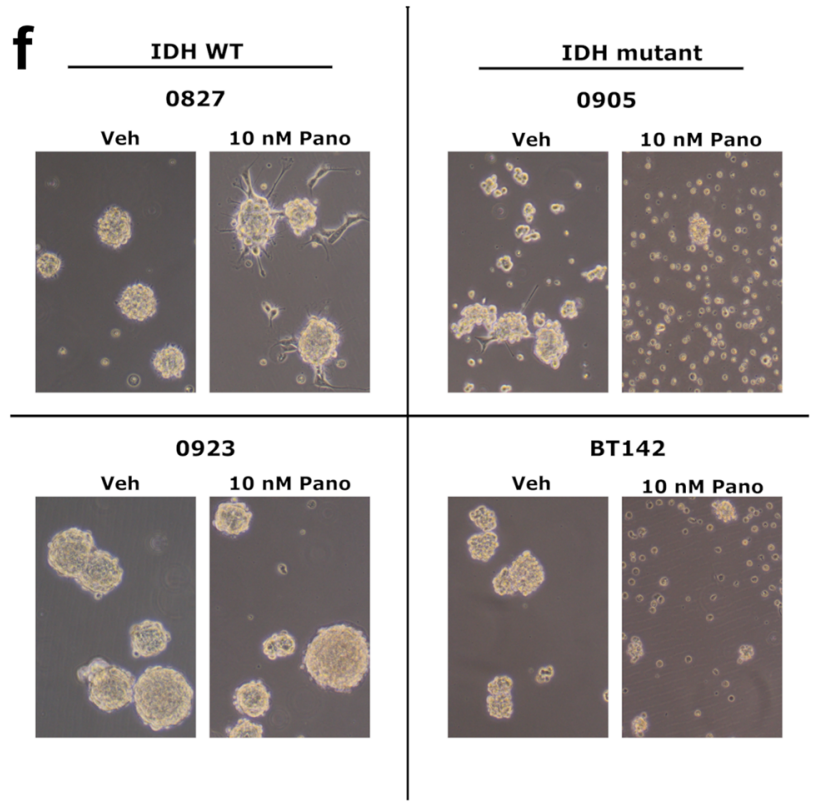

5 days $(n=3)$. Nonlinear regression statistical analysis was utilized to determine IC50 values. d Consolidation of apoptosis EC50 values derived from $\mathbf{c}$ stratified based on IDH status $(n=9)$. Statistical analysis was performed via Student's t-test. e Western blot of cleaved caspase 3 in whole cell lysates extracted from IDH1/2 ${ }^{\mathrm{wt}}$ and IDH $1^{\mathrm{mut}}$ glioma cells treated with $10 \mathrm{nM}$ panobinostat for 5 days. $f$ Phase-contrast microscopy of IDH1/2 ${ }^{\mathrm{wt}}$ and IDH $1^{\text {mut }}$ glioma cells treated with $10 \mathrm{nM}$ panobinostat for 5 days 
preferentially sensitive to the cytotoxic effects of the HDACi panobinostat.

\section{Panobinostat preferentially inhibits cell proliferation in IDH1 ${ }^{\text {mut }}$ glioma cells}

To determine the effect of panobinostat on IDH1/2 ${ }^{\text {wt }}$ versus IDH $1^{\text {mut }}$ glioma cell proliferation, cells were treated with panobinostat, then subjected to BrdU proliferation assays. Whereas $10 \mathrm{nM}$ panobinostat suppressed IDH1/2 ${ }^{\text {wt }}$ cell proliferation by $33 \%$ on average, it suppressed IDH $1^{\text {mut }}$ proliferation by $89.5 \%$ (Fig. 3a, b; Fig. S6a, b). The difference was much smaller, though still statistically significant, at $100 \mathrm{nM}$ panobinostat. Cell cycle analysis further supported the notion that IDH $1^{\text {mut }}$ cells are more sensitive to panobinostat, with a statistically significant induction of G1 arrest/ reduction in G2-M phase only observed in IDH1 ${ }^{\text {mut }}$ cells (Fig. 3c; Fig. S7). Finally, $10 \mathrm{nM}$ panobinostat suppressed the pro-proliferation MAPK and AKT signaling pathways in IDH $1^{\text {mut }}$ cells, not IDH1/2 ${ }^{\text {wt }}$ cells (Fig. 3d). Further, the cell cycle suppressor, p21, was variably induced by panobinostat in both IDH1 ${ }^{\text {mut }}$ cell lines tested, and in only one of the IDH1/2 ${ }^{\text {wt }}$ cell lines (Fig. 3e). No effects were seen on the related cell cycle inhibitor p16 (Fig. 3e). Together, these data suggest that, in addition to increased cytotoxicity, IDH $1^{\text {mut }}$ glioma cells are also preferentially sensitive to the antiproliferative effects of HDACi.

\section{HDACi elicits a greater increase in histone H3 acetylation in IDH $1^{\text {mut }}$ glioma cells}

Both IDH1/2 ${ }^{\text {wt }}$ and IDH1 ${ }^{\text {mut }}$ glioma cells responded to panobinostat with increased H3K14/18/27Ac histone marks (Fig. 4a). However, IDH1 ${ }^{\text {mut }}$ cells showed a three to sixfold induction in those marks, compared to a twofold increase in IDH $1 / 2^{\text {wt }}$ cells (Fig. 4b, c; Fig. S8). To evaluate global changes in histone acetylation, an ELISA against total H3KAc was used, which showed that total H3KAc content increased by $20 \%$ at $10 \mathrm{nM}$ panobinostat, and $35 \%$ at $50 \mathrm{nM}$ panobinostat, with IDH1 ${ }^{\text {mut }}$ cells showing an approximate twofold increase in H3KAc compared to IDH $1 / 2^{\text {wt }}$ cells (Fig. 4d, e). These data indicate that the heightened cytotoxic and antiproliferative effects by panobinostat in IDH $1^{\text {mut }}$ glioma cells are associated with a preferential increase in acetylated chromatin.

\section{IDH $1^{\text {mut }}$ glioma cells are also more sensitive to the HDACi valproic acid}

To investigate whether other HDACi are also preferentially active against IDH $1^{\text {mut }}$ glioma cells, IDH $1 / 2^{\text {wt }}$ and IDH $1^{\text {mut }}$ cells were treated with valproic acid (VPA), an antiepileptic with HDACi properties [25]. As with panobinostat,
VPA was more toxic to IDH1 ${ }^{\text {mut }}$ cells than IDH $1 / 2^{\text {wt }}$ cells, with an $\mathrm{IC}_{50}$ of $\sim 2 \mathrm{mM}$ for IDH1 ${ }^{\text {mut }}$ cells versus $4.6 \mathrm{mM}$ for IDH1/2 ${ }^{\text {wt }}$ cells (Fig. 5, Fig. S9).

\section{Discussion}

Despite the comparatively longer survival of patients with IDH1 ${ }^{\text {mut }}$ gliomas versus IDH1/2 ${ }^{\text {wt }}$ glioblastomas, IDH1 ${ }^{\text {mut }}$ gliomas remain an ultimately fatal, incurable disease, and thus new treatment options are needed for these tumors. Targeting the canonical IDH1 R132H variant, both by small molecule inhibitors and by a vaccine, are in clinical trials [26-28]. Other therapeutic strategies exploiting potential metabolic vulnerabilities in IDH $1^{\text {mut }}$ gliomas, including inhibitors of poly (ADP-ribose) polymerase and nicotinamide phosphoribosyltransferase, are also being pursued [29-31]. Yet, to date, comparatively little has been done to target the unique effects of IDH $1^{\text {mut }}$ on the glioma epigenome and chromatin.

In this study, we showed that cultured IDH $1^{\text {mut }}$ glioma cells are more sensitive than IDH $1 / 2^{\text {wt }}$ cells to the FDAapproved pan-HDACi, panobinostat, and that this is mediated through both cytotoxic and cytostatic effects (Figs. 2 and 3). This contrasts with some other IDH $1^{\text {mut }}$-specific cancer therapies, such as selective IDH $1{ }^{\text {mut }}$ inhibitors that suppress proliferation but are not cytotoxic [20]. Panobinostat was effective against IDH $1^{\text {mut }}$ cells cultured in either serum free media (0905 and BT142) or serum-supplemented media (TB096), suggesting that the effect is not unique to a particular glioma cell type or culture condition. Even BT142 cells, which deleted the wild-type IDH1 allele and therefore no longer produce as much D2HG, were still more sensitive to panobinostat and therefore suggest a durable therapeutic response. This indicates that HDACi may still be a useful strategy against IDH1 ${ }^{\text {mut }}$ gliomas that have decreased D2HG production during disease progression. Additionally, the ribosomal inhibitor, puromycin, was not more active against IDH $1^{\text {mut }}$ glioma cells, demonstrating that the effects of panobinostat are unlikely to be the result of a more generalized chemosensitivity of IDH $1^{\text {mut }}$ cells.

One key finding in this data is the greater upregulation of total histone $\mathrm{H} 3$ acetylation in IDH $1^{\text {mut }}$ glioma cells treated with panobinostat, specifically in H3K14/18/27Ac active chromatin marks (Fig. 4). Such upregulation may be driving the increased sensitivity of IDH $1^{\text {mut }}$ cells to HDACi. Our data suggests that this sensitivity may be due to enhanced regulation of the acetylome in IDH $1^{\text {mut }}$ glioma due to increased HDAC activity (Fig. 1). Considering that panobinostat is a pan-HDACi, future experiments will investigate the role of specific HDAC isoforms in mediating increases in histone acetylation in response 


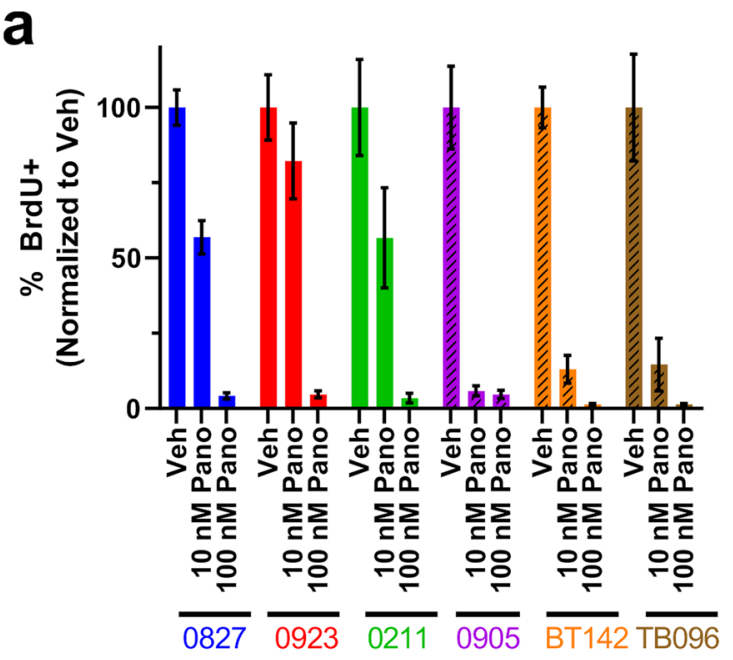

b
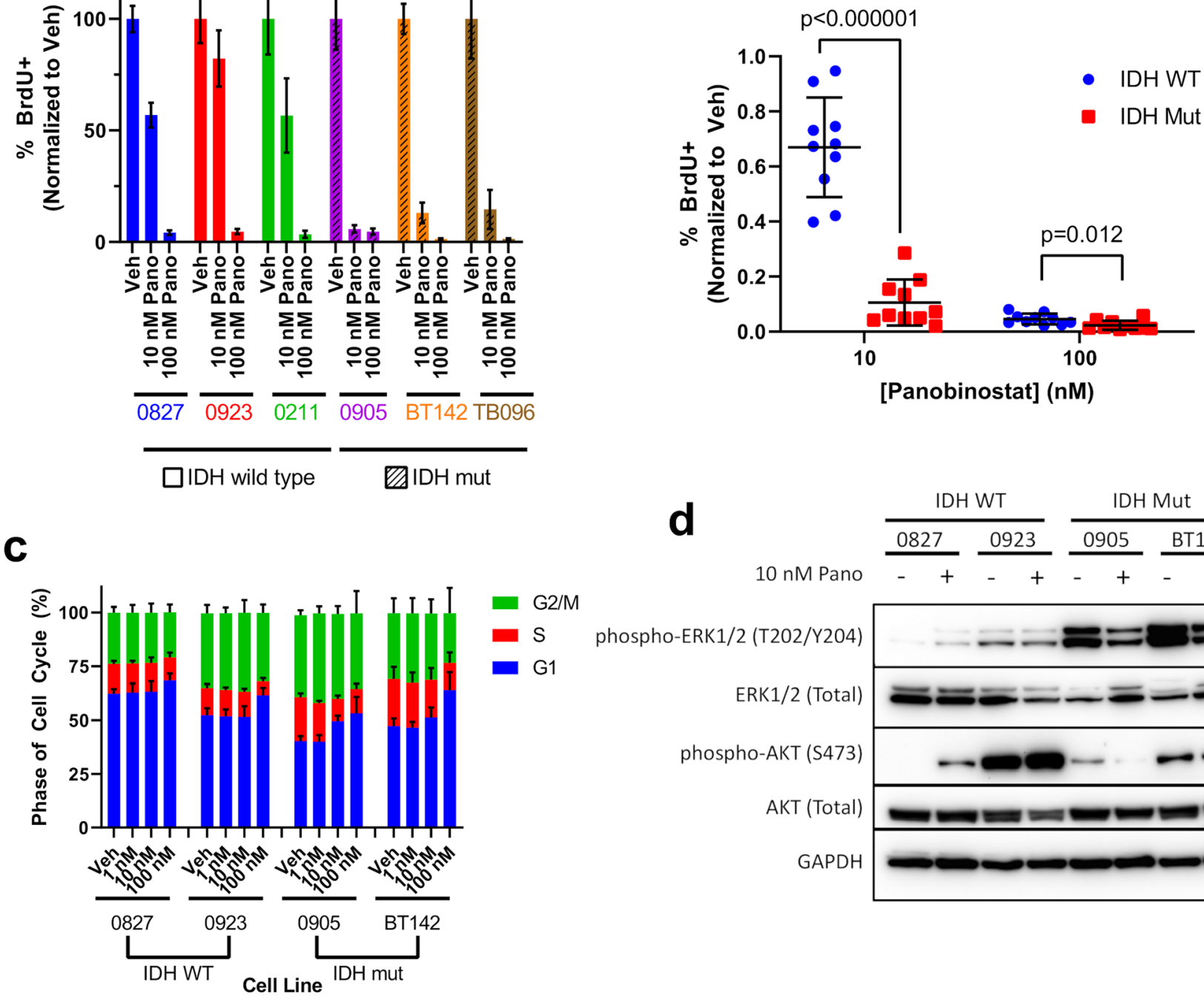

d
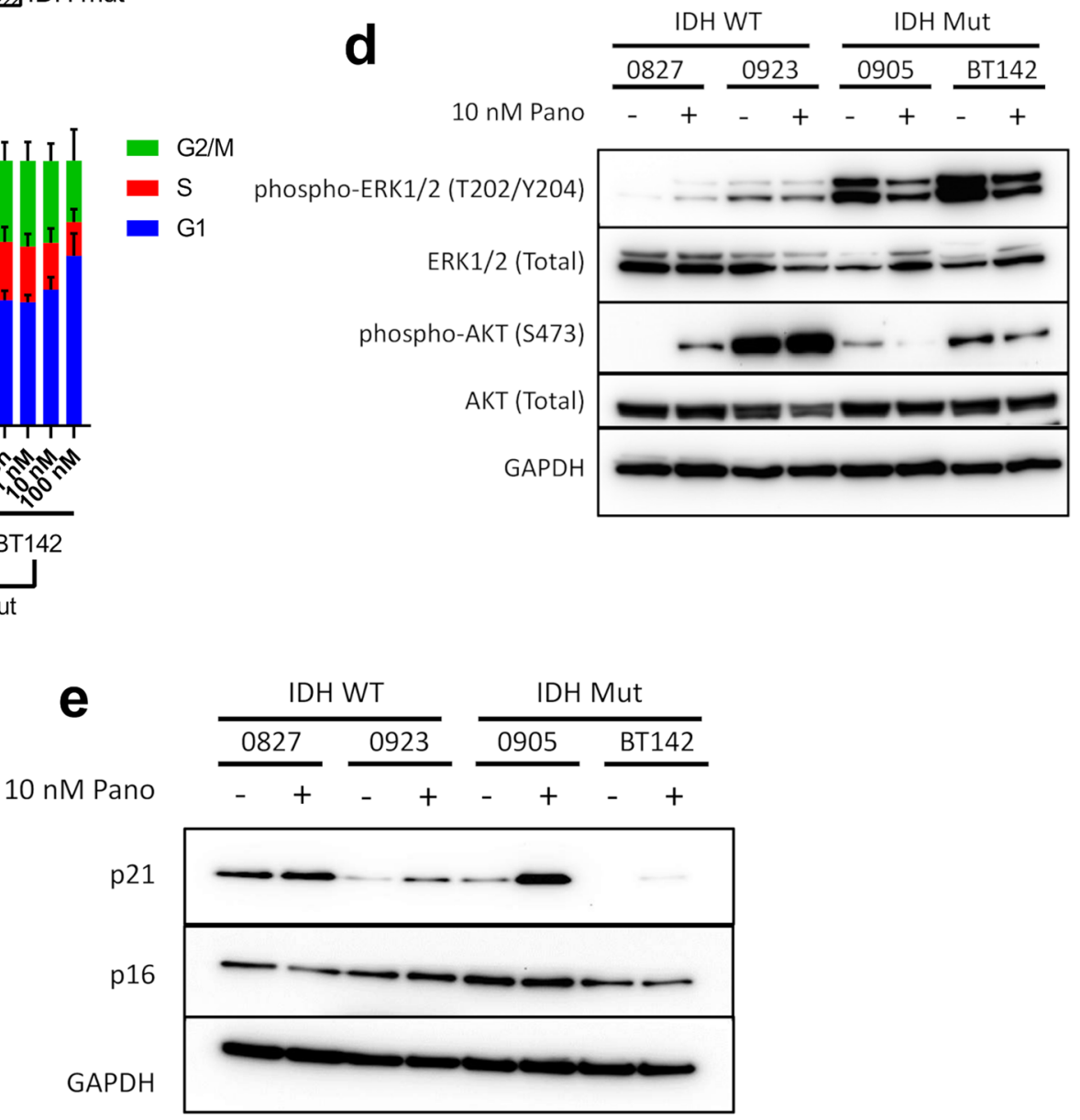

Fig. 3 Panobinostat preferentially reduces proliferation in IDH $1^{\text {mut }}$ glioma. a BrdU incorporation assays of IDH $1 / 2^{\text {wt }}$ and IDH $1^{\text {mut }}$ glioma treated with $10 \mathrm{nM}$ and $100 \mathrm{nM}$ panobinostat for $48 \mathrm{~h}(\mathrm{n}=3)$. b Consolidation of data from a stratified based on IDH status $(n=6$ for IDH $1 / 2^{\text {wt }}$ and $n=9$ for IDH $1^{\text {mut }}$ ). Statistical analysis was performed via Student's t-test. c Cell cycle analysis of IDH $1 / 2^{\text {wt }}$ and IDH1 $1^{\text {mut }}$ glioma treated with $20 \mathrm{nM}$ and $100 \mathrm{nM}$ panobinostat for $48 \mathrm{~h}(\mathrm{n}=3)$. d Western blot of ERK and AKT in whole cell lysates extracted from IDH1/2 ${ }^{\text {wt }}$ and IDH $1^{\text {mut }}$ glioma cells treated with $10 \mathrm{nM}$ panobinostat for 2 days. e Western blot of p21 and p16 in whole cell lysates extracted from IDH $1 / 2^{\mathrm{wt}}$ and IDH $1^{\text {mut }}$ glioma cells treated with $10 \mathrm{nM}$ panobinostat for 2 days 


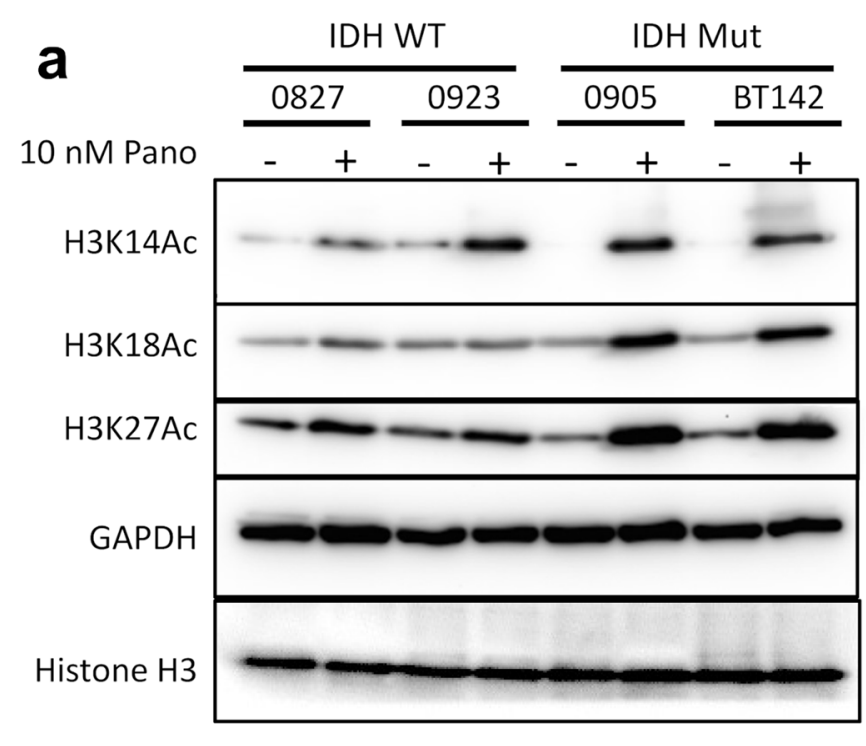

b

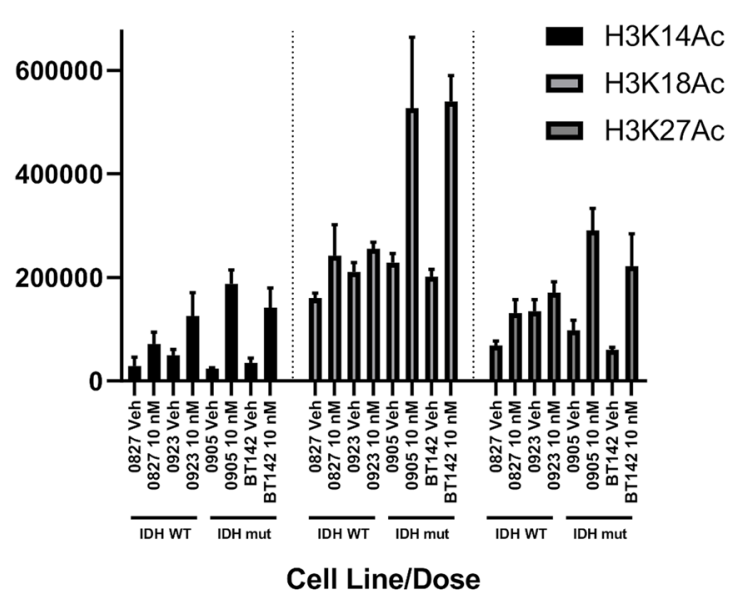

C

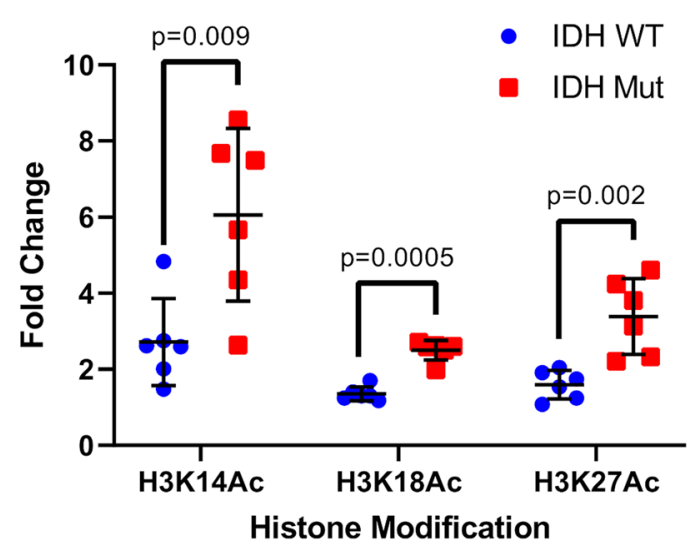

e

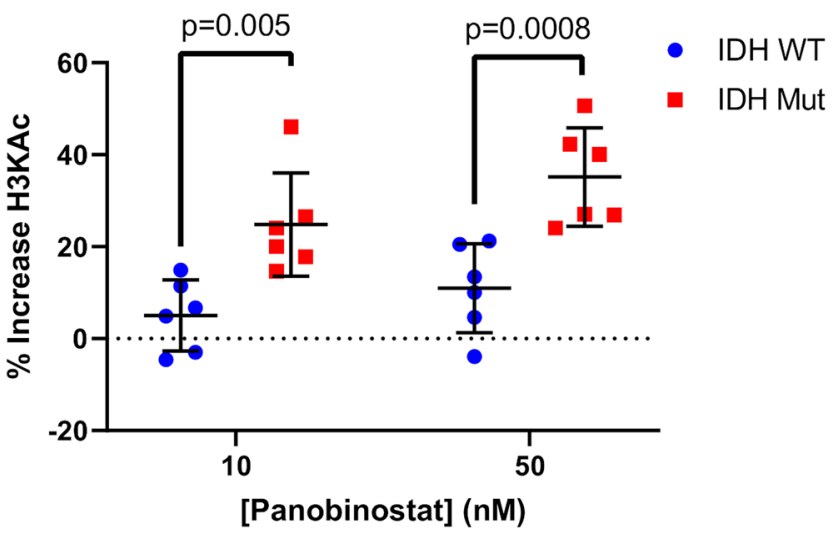

Fig. 4 IDH $1^{\text {mut }}$ glioma preferentially upregulates Histone H3 acetylation in response to panobinostat treatment. a Western blot of H3K14Ac, H3K18Ac, and H3K27Ac in whole cell lysates extracted from IDH $1 / 2^{\text {wt }}$ and IDH $1^{\text {mut }}$ glioma cells treated with $10 \mathrm{nM}$ panobinostat for 2 days. b Densitometry analysis of H3K14Ac, H3K18Ac, and H3K27Ac western blots normalized to GAPDH. Whole cell lysates were extracted from IDH $1 / 2^{\mathrm{wt}}$ and IDH $1^{\text {mut }}$ glioma cells treated with $10 \mathrm{nM}$ panobinostat for 2 days. Plots show total signal based on three independent experiments. c Consolidation of data from $\mathbf{b}$ stratified based on IDH status $(n=6)$ showing fold change in H3K14Ac, H3K18Ac, and H3K27Ac in response to $10 \mathrm{nM}$ panobinostat for 2 days. Statistical analysis was performed via Student's t-test. d Total H3KAc levels analyzed via ELISA in nuclear extracts from IDH $1 / 2^{\text {wt }}$ and IDH $1^{\text {mut }}$ glioma cells treated with 10 and $50 \mathrm{nM}$ panobinostat for 2 days $(n=3)$. e Consolidation of data from $\mathbf{d}$ stratified based on IDH status $(n=6)$. Statistical analysis was performed via Student's t-test 

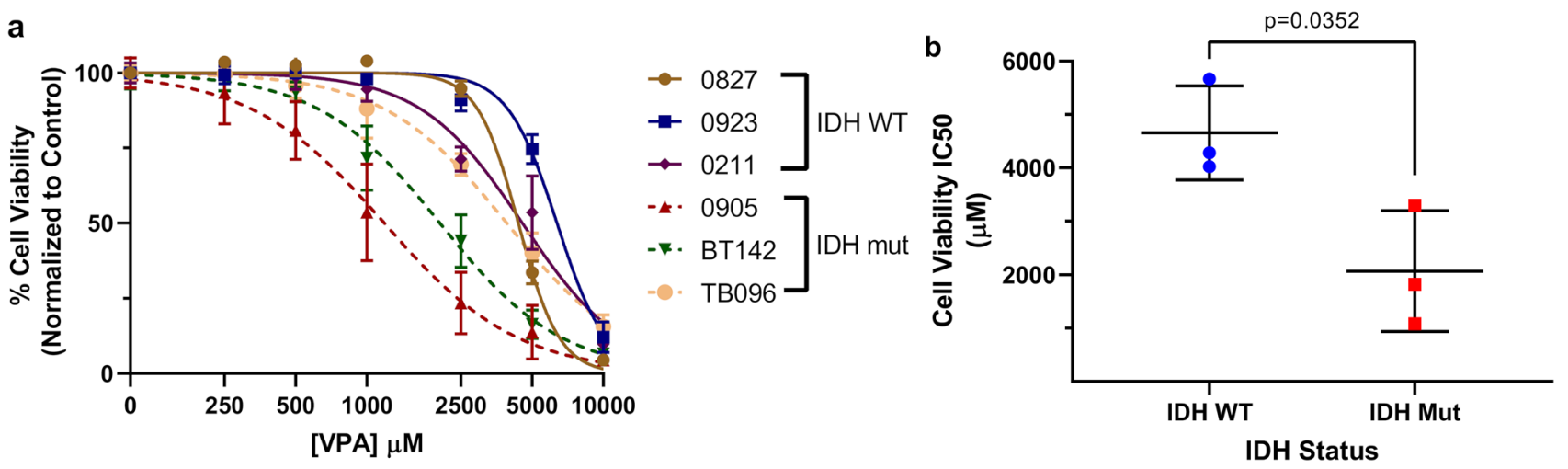

Fig. 5 Valproic acid recapitulates the preferential cytotoxicity in IDH $1^{\text {mut }}$ glioma. a Normalized cell viability of IDH $1 / 2^{\text {wt }}$ and IDH $1^{\text {mut }}$ glioma cells treated with the HDAC inhibitor valproic acid for 5 days $(n=3)$. Nonlinear regression statistical analysis was uti-

to panobinostat, as well as to determine the potential of HDACi against in vivo models of IDH1 ${ }^{\text {mut }}$ gliomas.

In addition to their proven role in treating multiple myeloma [18], HDACi are being explored in a number of other solid tumors, including glioblastomas and diffuse intrinsic pontine gliomas [32-35]. However, results thus far in IDH $1 / 2^{\text {wt }}$ glioblastoma patients have been disappointing [36-38]. One study that did include 10 IDH $1^{\text {mut }}$ astrocytoma patients was inconclusive, perhaps in part because of a reliance on historical controls, and an exclusive focus on recurrent cases that had already been treated with standard therapy [39]. A recent study by others suggested that IDH $1^{\text {mut }}$ gliomas were actually more resistant to HDACi [40]; however, that study used overexpression of IDH1 R132H in U87MG and U373MG glioblastoma cells. Our data demonstrate the importance of using patient-derived models, with endogenous IDH ${ }^{\text {mut }}$, when studying therapeutics aimed at altering the epigenome and/or chromatin.

In this study, another HDACi, VPA, was also more effective against IDH $1{ }^{\text {mut }}$ glioma cells (Fig. 5). VPA has already been tested in clinical trials against IDH $1 / 2^{\mathrm{wt}}$ pediatric and adult gliomas, with varying results [41-43]. To date, however, it has not been tested specifically in patients with IDH1 ${ }^{\text {mut }}$ gliomas. Considering that VPA is a powerful antiepileptic often used to control seizures in glioma patients, and that IDH $1{ }^{\text {mut }}$ gliomas are highly epileptogenic [44], VPA might have a dual purpose in IDH1 ${ }^{\text {mut }}$ glioma patients.

In summary, we identified that cultured glioma cells with endogenous IDH $1{ }^{\mathrm{mut}}$ are preferentially sensitive to the cytotoxic and antiproliferative effects of the FDA-approved HDACi, including panobinostat and valproic acid. HDACi increases the amount of acetylated chromatin in IDH1 ${ }^{\text {mut }}$, providing a potential molecular rationale for this increased sensitivity to HDACi. In sum, this study suggests the lized to determine IC50 values. b Consolidation of cell viability IC50 values from a stratified based on IDH status $(n=9)$. Statistical analysis was performed via Student's t-test

potential of HDACi inhibition as a therapeutic strategy specifically for the treatment of IDH $1^{\text {mut }}$ glioma.

\section{Materials and methods}

\section{Cell lines}

Glioma stem cells 0827, 0923, 0211 and 0905 were previously isolated at the Neuro-Oncology Branch, NIH and have been previously characterized for glioma stem-like properties and genomic alterations [22-25]. BT142 [26] was purchased from ATCC, while TB096 [11] was a kind gift from Dr. Hai Yan at Duke University. All cell lines were grown in medium that includes Neurobasal-A base medium, B-27 and N2 supplements along with EGF and FGF growth factors (NBE). Two cell lines, 0905 and BT142, required $100 \mathrm{ng} /$ mL PDGF-AA in the medium. TB096 was cultured in half NBE and half DMEM with $10 \%$ FBS. All cell cultures were cultured at $37 \mathrm{C}$ and $5 \% \mathrm{CO} 2$ with $1 \times$ penstrep and were frequently monitored for mycoplasma contamination. Additionally, cells were cultured in suspension as neurospheres except for TB096 which exhibited adherent growth. Cell culture medium was changed $3 \mathrm{x} /$ week. Panobinostat (Fischer Scientific; NC0021665) was dissolved in 100\% DMSO, sterile filtered, and diluted to $1000 \times$ in DMSO for drug treatments. For all treatments, vehicle concentrations were $0.1 \%$ or less.

\section{Analysis of TCGA and CGGA Data}

Gene expression data from TCGA and CGGA datasets was downloaded as raw counts and processed using the online tool Appyter [19, 20, 45]. DEGs between IDH ${ }^{\mathrm{w} / \mathrm{mut}}$ gliomas were generated using the Limma package with a p-value 
cutoff of 0.05 and a fold change cutoff of 0.2. GO analysis employed the use of the online tool Enrichr using the top 1000 DEGs [45]. Gene expression plots were created by uploading data to the UCSC Xena Browser, organizing data by IDH status and tumor grade, and then generating grade- and IDH-matched gene expression boxplots with corresponding t-test statistics [46].

\section{Cell viability and apoptosis assays}

Cell viability and apoptosis assays were conducted using a Luminex Guava ${ }^{\circledR}$ Muse ${ }^{\circledR}$ Cell Analyzer in conjunction with a Muse ${ }^{\circledR}$ Cell Count and Viability Kit or a Muse ${ }^{\circledR}$ Annexin $\mathrm{V}$ and Dead Cell Kit. Single-cell suspensions were analyzed on the Muse ${ }^{\circledR}$ Cell Analyzer according to the manufacturer's protocols. Briefly, cells were trypsinized $(0.05 \%)$ and then mixed with Cell Count and Viability reagent or 1:1 NBE to Annexin V and Dead Cell reagent, incubated for the specified amount of time on manufacturer's protocol, and then inserted into the Muse ${ }^{\circledR}$ Cell Analyzer for data acquisition.

\section{Phase-contrast microscopy}

Phase-contrast microscopy was performed using an Olympus CK40 inverted microscope with a Canon EOS 700D camera mounted via an OM-Mount Photomicro Adapter L. Briefly, cells were placed on the microscope stage, allowed to settle, and 2-3 images were taken of different fields of view. Images were captured using the EOS Utility software.

\section{Immunoblotting}

Cell samples were washed with $1 \mathrm{X}$ DPBS, pelleted via centrifugation, flash-frozen in liquid nitrogen, and finally stored at $-80{ }^{\circ} \mathrm{C}$ until cell lysis. Total cell extracts were prepared by resuspending cell pellets in $1 \times$ RIPA buffer containing $1 \times$ protease and phosphatase inhibitor and then subjecting pellets to sonication for $3 \times 20 \mathrm{~s}$. Insoluble fractions were pelleted and discarded, and then subsequent protein quantitation was performed on clarified cell lysates via Bradford assay. SDS-PAGE and transfer steps were conducted via the Novex immunoblot system. Blots were visualized using a ProteinSimple Fluorchem ${ }^{\circledR}$ E Imager. Bands on immunoblots were quantified via AlphaView SA v3.5. Quantified immunoblots all experienced the same transfer conditions, primary/secondary antibody concentrations, and exposure times. Antibody information can be found in Supplementary Methods.

\section{Enzyme-linked immunosorbent assay (ELISA)}

Detection of intracellular 2-HG levels was performed using the Abcam D-2-Hydroxyglutarate Assay kit (ab211070) according to the manufacturer's protocol. Briefly, cells were trypsinized $(0.05 \%)$, pelleted via centrifugation, and flash frozen in liquid nitrogen. Once ready for further analysis, cells were lysed according to manufacturer's protocol, stably spotted on strip-wells, and then processed for final colorimetric analysis at $450 \mathrm{~nm}$ via a Molecular Devices SpectraMax ${ }^{\circledR} 340$ microplate reader.

Detection of total histone $\mathrm{H} 3$ acetylation was performed via Epigentek's EpiQuik ® Global Histone H3 Acetylation Assay kit according to the manufacturer's protocol. Briefly, histones were acid extracted, stably spotted on strip-wells, and antibodies bound to antigen. Finally, samples were analyzed colorimetrically at $450 \mathrm{~nm}$ and quantified via standard curve.

\section{Cell cycle analysis}

Cells were analyzed for changes in cell cycle distribution via Muse ${ }^{\circledR}$ Cell Cycle kit according to manufacturer's protocol. Briefly, cells were trypsinized $(0.05 \%)$ to form a single cell suspension, washed with $1 \times$ DPBS, and fixed in $70 \%$ ethanol at $-20{ }^{\circ} \mathrm{C}$ overnight. Fixed cells were then incubated with Muse ${ }^{\circledR}$ Cell Cycle reagent for $30 \mathrm{~min}$ at room temp away from light and then injected onto the Muse Cell Analyzer.

\section{BrdU incorporation assays}

Cells were analyzed for BrdU incorporation via BD Pharmingen ${ }^{\circledR}$ BrdU Flow kit according to the manufacturer's protocol. Briefly, cells were treated for $48 \mathrm{~h}$ with drug and then pulsed with $10 \mu \mathrm{M}$ BrdU (except for our No BrdU control) for $2.5 \mathrm{~h}$ before washing, fixing, and storing at $-80{ }^{\circ} \mathrm{C}$ in solution of 1:9 FBS to DMSO. When ready for analysis, cells were then thawed, permeabilized, and incubated with anti-BrdU antibody according to manufacturer's protocol. Once stained cell samples and unstained controls were ready for analysis, data was acquired using a Beckman Coulter Cytomics ${ }^{\circledR}$ FC500 flow cytometer with FITC filter applied. Cells were gated using the No BrdU control and then treated samples were assessed for BrdU-positive cells within this gate (Supplementary Figure).

\section{Statistical analyses}

Student's t test and nonlinear regression statistical analyses were performed via GraphPad Prism 8.0 software package. All replicate analyses are presented as mean \pm standard deviation of three independent replicates at a significance level $(\alpha)$ of 0.05 unless otherwise indicated in the figure captions.

Supplementary Information The online version contains supplementary material available at https://doi.org/10.1007/s11060-021-03829-0. 
Acknowledgements This research was supported by the UC Davis Floyd and Mary Schwall Dissertation Fellowship, the UC Davis Murray B. Gardner Junior Faculty Research Fellowship, and the Elsa U. Pardee Foundation Research Grant.

Author contributions Conceptualization: TS, KW; methodology: TS, $\mathrm{CH}, \mathrm{KW}$; formal analysis and investigation: TS; writing — original draft preparation: TS; writing - review and editing: TS, $\mathrm{CH}$, KW; funding acquisition: TS, KW; resources: TS, KW; supervision: $\mathrm{KW}$.

Funding This study was funded by the UC Davis Schwall Dissertation Fellowship and UC Davis La Pittus Fellowship. CH was supported by NIH grants R01NS118039, R01NS117104, R01NS102669, and P50CA221747.

\section{Declarations}

Conflict of interest The authors declare that they have no conflict of interest.

Open Access This article is licensed under a Creative Commons Attribution 4.0 International License, which permits use, sharing, adaptation, distribution and reproduction in any medium or format, as long as you give appropriate credit to the original author(s) and the source, provide a link to the Creative Commons licence, and indicate if changes were made. The images or other third party material in this article are included in the article's Creative Commons licence, unless indicated otherwise in a credit line to the material. If material is not included in the article's Creative Commons licence and your intended use is not permitted by statutory regulation or exceeds the permitted use, you will need to obtain permission directly from the copyright holder. To view a copy of this licence, visit http://creativecommons.org/licenses/by/4.0/.

\section{References}

1. Horbinski C (2013) What do we know about IDH1/2 mutations so far, and how do we use it? Acta Neuropathol 125:621-636. https:// doi.org/10.1007/s00401-013-1106-9

2. Dang L, White DW, Gross S, Bennett BD, Bittinger MA, Driggers EM, Fantin VR, Jang HG, Jin S, Keenan MC, Marks KM, Prins RM, Ward PS, Yen KE, Liau LM, Rabinowitz JD, Cantley LC, Thompson CB, Vander Heiden MG, Su SM (2009) Cancerassociated IDH1 mutations produce 2-hydroxyglutarate. Nature 462:739-744

3. Turcan S, Rohle D, Goenka A, Walsh LA, Fang F, Yilmaz E, Campos C, Fabius AW, Lu C, Ward PS, Thompson CB, Kaufman A, Guryanova O, Levine R, Heguy A, Viale A, Morris LG, Huse JT, Mellinghoff IK, Chan TA (2012) IDH1 mutation is sufficient to establish the glioma hypermethylator phenotype. Nature 483:479-483. https://doi.org/10.1038/nature10866

4. Xu W, Yang H, Liu Y, Yang Y, Wang P, Kim S-H, Ito S, Yang C, Wang P, Xiao M-T (2011) Oncometabolite 2-hydroxyglutarate is a competitive inhibitor of $\alpha$-ketoglutarate-dependent dioxygenases. Cancer Cell 19:17-30

5. Duncan CG, Barwick BG, Jin G, Rago C, Kapoor-Vazirani P, Powell DR, Chi J-T, Bigner DD, Vertino PM, Yan H (2012) A heterozygous IDH1(R132H/WT) mutation induces genome-wide alterations in DNA methylation. Genome Res 22:2339-2355. https://doi.org/10.1101/gr.132738.111

6. Brat DJ, Aldape K, Colman H, Holland EC, Louis DN, Jenkins RB, Kleinschmidt-DeMasters BK, Perry A, Reifenberger G, Stupp
R, von Deimling A, Weller M (2018) cIMPACT-NOW update 3: recommended diagnostic criteria for "Diffuse astrocytic glioma, IDH-wildtype, with molecular features of glioblastoma, WHO grade IV." Acta Neuropathol 136:805-810

7. Noushmehr H, Weisenberger DJ, Diefes K, Phillips HS, Pujara K, Berman BP, Pan F, Pelloski CE, Sulman EP, Bhat KP, Verhaak RG, Hoadley KA, Hayes DN, Perou CM, Schmidt HK, Ding L, Wilson RK, Van Den Berg D, Shen H, Bengtsson H, Neuvial P, Cope LM, Buckley J, Herman JG, Baylin SB, Laird PW, Aldape $\mathrm{K}$ (2010) Identification of a $\mathrm{CpG}$ island methylator phenotype that defines a distinct subgroup of glioma. Cancer Cell 17:510-522. https://doi.org/10.1016/j.ccr.2010.03.017

8. Mazor T, Chesnelong C, Pankov A, Jalbert LE, Hong C, Hayes J, Smirnov IV, Marshall R, Souza CF, Shen Y, Viswanath P, Noushmehr H, Ronen SM, Jones SJM, Marra MA, Cairncross JG, Perry A, Nelson SJ, Chang SM, Bollen AW, Molinaro AM, Bengtsson $\mathrm{H}$, Olshen AB, Weiss S, Phillips JJ, Luchman HA, Costello JF (2017) Clonal expansion and epigenetic reprogramming following deletion or amplification of mutant IDH1. Proc Natl Acad Sci USA 114:10743-10748. https://doi.org/10.1073/pnas.1708914114

9. Moure CJ, Diplas BH, Chen LH, Yang R, Pirozzi CJ, Wang Z, Spasojevic I, Waitkus MS, He Y, Yan H (2019) CRISPR editing of mutant IDH1 R132H induces a CpG methylation-low state in patient-derived glioma models of G-CIMP. Mol Cancer Res 17:2042-2050

10. Turcan S, Makarov V, Taranda J, Wang Y, Fabius AWM, Wu W, Zheng Y, El-Amine N, Haddock S, Nanjangud G (2018) MutantIDH1-dependent chromatin state reprogramming, reversibility, and persistence. Nat Genet 50:62-72

11. Brehm A, Miska EA, McCance DJ, Reid JL, Bannister AJ, Kouzarides T (1998) Retinoblastoma protein recruits histone deacetylase to repress transcription. Nature 391:597-601

12. Feng Q, Zhang Y (2001) The MeCP1 complex represses transcription through preferential binding, remodeling, and deacetylating methylated nucleosomes. Genes Dev 15:827-832

13. Jones PL, Veenstra GJ, Wade PA, Vermaak D, Kass SU, Landsberger N, Strouboulis J, Wolffe AP (1998) Methylated DNA and $\mathrm{MeCP} 2$ recruit histone deacetylase to repress transcription. Nat Genet 19:187-191

14. Zhang Y, Ng H-H, Erdjument-Bromage H, Tempst P, Bird A, Reinberg D (1999) Analysis of the NuRD subunits reveals a histone deacetylase core complex and a connection with DNA methylation. Genes Dev 13:1924-1935

15. Desai MA, Webb HD, Sinanan LM, Scarsdale JN, Walavalkar NM, Ginder GD, Williams DC Jr (2015) An intrinsically disordered region of methyl-CpG binding domain protein 2 (MBD2) recruits the histone deacetylase core of the NuRD complex. Nucleic Acids Res 43:3100-3113

16. Basta J, Rauchman M (2015) The nucleosome remodeling and deacetylase complex in development and disease. Transl Res 165:36-47

17. Zhan X, Guo S, Li Y, Ran H, Huang H, Mi L, Wu J, Wang X, Xiao D, Chen L (2020) Glioma stem-like cells evade interferon suppression through MBD3/NuRD complex-mediated STAT1 downregulation. J Exp Med. https://doi.org/10.1084/jem.20191 340

18. San-Miguel JF, Hungria VT, Yoon SS, Beksac M, Dimopoulos MA, Elghandour A, Jedrzejczak WW, Günther A, Nakorn TN, Siritanaratkul N, Corradini P, Chuncharunee S, Lee JJ, Schlossman RL, Shelekhova T, Yong K, Tan D, Numbenjapon T, Cavenagh JD, Hou J, LeBlanc R, Nahi H, Qiu L, Salwender H, Pulini S, Moreau P, Warzocha K, White D, Bladé J, Chen W, de la Rubia J, Gimsing P, Lonial S, Kaufman JL, Ocio EM, Veskovski L, Sohn SK, Wang MC, Lee JH, Einsele H, Sopala M, Corrado C, Bengoudifa BR, Binlich F, Richardson PG (2014) Panobinostat plus bortezomib and dexamethasone versus placebo 
plus bortezomib and dexamethasone in patients with relapsed or relapsed and refractory multiple myeloma: a multicentre, randomised, double-blind phase 3 trial. Lancet Oncol 15:1195-1206. https://doi.org/10.1016/s1470-2045(14)70440-1

19. Zhao Z, Meng F, Wang W, Wang Z, Zhang C, Jiang T (2017) Comprehensive RNA-seq transcriptomic profiling in the malignant progression of gliomas. Sci Data. https://doi.org/10.1038/ sdata.2017.24

20. Tomczak K, Czerwińska P, Wiznerowicz M (2015) The Cancer Genome Atlas (TCGA): an immeasurable source of knowledge. Contemp Oncol 19:A68

21. AACR Project GENIE Consortium (2017) AACR Project GENIE: powering precision medicine through an International Consortium. Cancer Discov 7:818-831. https://doi.org/10.1158/21598290.Cd-17-0151

22. Pietrak B, Zhao H, Qi H, Quinn C, Gao E, Boyer JG, Concha N, Brown K, Duraiswami C, Wooster R, Sweitzer S, Schwartz B (2011) A tale of two subunits: how the neomorphic R132H IDH1 mutation enhances production of alphaHG. Biochemistry 50:4804-4812. https://doi.org/10.1021/bi200499m

23. Jin G, Reitman ZJ, Duncan CG, Spasojevic I, Gooden DM, Rasheed BA, Yang R, Lopez GY, He Y, McLendon RE, Bigner DD, Yan H (2013) Disruption of wild-type IDH1 suppresses D-2-hydroxyglutarate production in IDH1-mutated gliomas. Cancer Res 73:496-501. https://doi.org/10.1158/0008-5472. CAN-12-2852

24. Ward PS, Lu C, Cross JR, Abdel-Wahab O, Levine RL, Schwartz GK, Thompson CB (2013) The potential for isocitrate dehydrogenase mutations to produce 2-hydroxyglutarate depends on allele specificity and subcellular compartmentalization. J Biol Chem 288:3804-3815. https://doi.org/10.1074/jbc.M112.435495

25. Göttlicher M (2004) Valproic acid: an old drug newly discovered as inhibitor of histone deacetylases. Ann Hematol 83(Suppl 1):S91-92. https://doi.org/10.1007/s00277-004-0850-2

26. Mellinghoff IK, Ellingson BM, Touat M, Maher E, De La Fuente MI, Holdhoff M, Cote GM, Burris H, Janku F, Young RJ, Huang R, Jiang L, Choe S, Fan B, Yen K, Lu M, Bowden C, Steelman L, Pandya SS, Cloughesy TF, Wen PY (2020) Ivosidenib in isocitrate dehydrogenase 1-mutated advanced glioma. J Clin Oncol 38:3398-3406

27. Andronesi OC, Loebel F, Bogner W, Marjanska M, Vander Heiden MG, Iafrate AJ, Dietrich J, Batchelor TT, Gerstner ER, Kaelin WG, Chi AS, Rosen BR, Cahill DP (2016) Treatment response assessment in IDH-mutant glioma patients by noninvasive 3D functional spectroscopic mapping of 2-hydroxyglutarate. Clin Cancer Res 22:1632-1641. https://doi.org/10.1158/1078-0432. ccr-15-0656

28. Platten M, Bunse L, Wick A, Bunse T, Le Cornet L, Harting I, Sahm F, Sanghvi K, Tan CL, Poschke I, Green E, Justesen S, Behrens GA, Breckwoldt MO, Freitag A, Rother LM, Schmitt A, Schnell O, Hense J, Misch M, Krex D, Stevanovic S, Tabatabai G, Steinbach JP, Bendszus M, von Deimling A, Schmitt M, Wick W (2021) A vaccine targeting mutant IDH1 in newly diagnosed glioma. Nature 592:463-468

29. Sulkowski PL, Corso CD, Robinson ND, Scanlon SE, Purshouse KR, Bai H, Liu Y, Sundaram RK, Hegan DC, Fons NR, Breuer GA, Song Y, Mishra-Gorur K, De Feyter HM, de Graaf RA, Surovtseva YV, Kachman M, Halene S, Gunel M, Glazer PM, Bindra RS (2017) 2-Hydroxyglutarate produced by neomorphic IDH mutations suppresses homologous recombination and induces PARP inhibitor sensitivity. Sci Transl Med. https://doi. org/10.1126/scitranslmed.aal2463

30. Tateishi $\mathrm{K}$, Wakimoto $\mathrm{H}$, Iafrate AJ, Tanaka S, Loebel F, Lelic N, Wiederschain D, Bedel O, Deng G, Zhang B, He T, Shi X, Gerszten RE, Zhang Y, Yeh JR, Curry WT, Zhao D, Sundaram S, Nigim F, Koerner MV, Ho Q, Fisher DE, Roider EM, Kemeny
LV, Samuels Y, Flaherty KT, Batchelor TT, Chi AS, Cahill DP (2015) Extreme vulnerability of IDH1 mutant cancers to NAD+ depletion. Cancer Cell 28:773-784. https://doi.org/10.1016/j. ccell.2015.11.006

31. Wang Y, Wild AT, Turcan S, Wu WH, Sigel C, Klimstra DS, Ma X, Gong Y, Holland EC, Huse JT, Chan TA (2020) Targeting therapeutic vulnerabilities with PARP inhibition and radiation in IDH-mutant gliomas and cholangiocarcinomas. Sci Adv. https:// doi.org/10.1126/sciadv.aaz3221

32. Nguyen TTT, Zhang Y, Shang E, Shu C, Torrini C, Zhao J, Bianchetti E, Mela A, Humala N, Mahajan A, Harmanci AO, Lei Z, Maienschein-Cline M, Quinzii CM, Westhoff MA, KarpelMassler G, Bruce JN, Canoll P, Siegelin MD (2020) HDAC inhibitors elicit metabolic reprogramming by targeting super-enhancers in glioblastoma models. J Clin Invest 130:3699-3716

33. Radoul M, Najac C, Viswanath P, Mukherjee J, Kelly M, Gillespie AM, Chaumeil MM, Eriksson P, Delos Santos R, Pieper RO, Ronen SM (2019) HDAC inhibition in glioblastoma monitored by hyperpolarized (13) C MRSI. NMR Biomed. https://doi.org/ $10.1002 / \mathrm{nbm} .4044$

34. Grasso CS, Tang Y, Truffaux N, Berlow NE, Liu L, Debily MA, Quist MJ, Davis LE, Huang EC, Woo PJ, Ponnuswami A, Chen S, Johung TB, Sun W, Kogiso M, Du Y, Qi L, Huang Y, HüttCabezas M, Warren KE, Le Dret L, Meltzer PS, Mao H, Quezado M, van Vuurden DG, Abraham J, Fouladi M, Svalina MN, Wang N, Hawkins C, Nazarian J, Alonso MM, Raabe EH, Hulleman E, Spellman PT, Li XN, Keller C, Pal R, Grill J, Monje M (2015) Functionally defined therapeutic targets in diffuse intrinsic pontine glioma. Nat Med 21:555-559

35. Hennika T, Hu G, Olaciregui NG, Barton KL, Ehteda A, Chitranjan A, Chang C, Gifford AJ, Tsoli M, Ziegler DS, Carcaboso AM, Becher OJ (2017) Pre-clinical study of panobinostat in xenograft and genetically engineered murine diffuse intrinsic pontine glioma models. PLoS ONE. https://doi.org/10.1371/journal.pone.01694 85

36. Puduvalli VK, Wu J, Yuan Y, Armstrong TS, Vera E, Wu J, Xu J, Giglio P, Colman H, Walbert T, Raizer J, Groves MD, Tran D, Iwamoto F, Avgeropoulos N, Paleologos N, Fink K, Peereboom D, Chamberlain M, Merrell R, Penas Prado M, Yung WKA, Gilbert MR (2020) A Bayesian adaptive randomized phase II multicenter trial of bevacizumab with or without vorinostat in adults with recurrent glioblastoma. Neuro Oncol 22:1505-1515

37. Galanis E, Anderson SK, Miller CR, Sarkaria JN, Jaeckle K, Buckner JC, Ligon KL, Ballman KV, Moore DF Jr, Nebozhyn M, Loboda A, Schiff D, Ahluwalia MS, Lee EQ, Gerstner ER, Lesser GJ, Prados M, Grossman SA, Cerhan J, Giannini C, Wen PY (2018) Phase I/II trial of vorinostat combined with temozolomide and radiation therapy for newly diagnosed glioblastoma: results of Alliance N0874/ABTC 02. Neuro Oncol 20:546-556

38. Friday BB, Anderson SK, Buckner J, Yu C, Giannini C, Geoffroy F, Schwerkoske J, Mazurczak M, Gross H, Pajon E, Jaeckle K, Galanis E (2012) Phase II trial of vorinostat in combination with bortezomib in recurrent glioblastoma: a north central cancer treatment group study. Neuro Oncol 14:215-221

39. Lee EQ, Reardon DA, Schiff D, Drappatz J, Muzikansky A, Grimm SA, Norden AD, Nayak L, Beroukhim R, Rinne ML, Chi AS, Batchelor TT, Hempfling K, McCluskey C, Smith KH, Gaffey SC, Wrigley B, Ligon KL, Raizer JJ, Wen PY (2015) Phase II study of panobinostat in combination with bevacizumab for recurrent glioblastoma and anaplastic glioma. Neuro Oncol 17:862-867

40. Kim GH, Choi SY, Oh TI, Kan SY, Kang H, Lee S, Oh T, Ko HM, Lim JH (2019) IDH1(R132H) causes resistance to HDAC inhibitors by increasing NANOG in glioblastoma cells. Int J Mol Sci. https://doi.org/10.3390/ijms20112679

41. Su JM, Murray JC, McNall-Knapp RY, Bowers DC, Shah S, Adesina AM, Paulino AC, Jo E, Mo Q, Baxter PA, Blaney SM 
(2020) A phase 2 study of valproic acid and radiation, followed by maintenance valproic acid and bevacizumab in children with newly diagnosed diffuse intrinsic pontine glioma or high-grade glioma. Pediatr Blood Cancer. https://doi.org/10.1002/pbc.28283

42. Weller M, Gorlia T, Cairncross JG, van den Bent MJ, Mason W, Belanger K, Brandes AA, Bogdahn U, Macdonald DR, Forsyth P, Rossetti AO, Lacombe D, Mirimanoff RO, Vecht CJ, Stupp R (2011) Prolonged survival with valproic acid use in the EORTC/NCIC temozolomide trial for glioblastoma. Neurology 77:1156-1164

43. Krauze AV, Myrehaug SD, Chang MG, Holdford DJ, Smith S, Shih J, Tofilon PJ, Fine HA, Camphausen K (2015) A phase 2 study of concurrent radiation therapy, temozolomide, and the histone deacetylase inhibitor valproic acid for patients with glioblastoma. Int J Radiat Oncol Biol Phys 92:986-992

44. Chen H, Judkins J, Thomas C, Wu M, Khoury L, Benjamin CG, Pacione D, Golfinos JG, Kumthekar P, Ghamsari F, Chen L, Lein P, Chetkovich DM, Snuderl M, Horbinski C (2017) Mutant IDH1 and seizures in patients with glioma. Neurology 88:1805-1813
45. Clarke DJB, Jeon M, Stein DJ, Moiseyev N, Kropiwnicki E, Dai C, Xie Z, Wojciechowicz ML, Litz S, Hom J, Evangelista JE, Goldman L, Zhang S, Yoon C, Ahamed T, Bhuiyan S, Cheng M, Karam J, Jagodnik KM, Shu I, Lachmann A, Ayling S, Jenkins SL, Ma'ayan A (2021) Appyters: Turning Jupyter Notebooks into data-driven web apps. Patterns. https://doi.org/10.1016/j.patter. 2021.100213

46. Goldman M, Craft B, Swatloski T, Cline M, Morozova O, Diekhans M, Haussler D, Zhu J (2015) The UCSC cancer genomics browser: update 2015. Nucl Acids Res 43:D812-D817

Publisher's Note Springer Nature remains neutral with regard to jurisdictional claims in published maps and institutional affiliations. 